\title{
Changing costs of public services
}

\section{Mike G Phelps \\ Office for National Statistics}

\section{SUMMARY}

This article presents new estimates of how much the unit costs of public services, such as the NHS and schools, have changed compared to unit costs in general: the change in the relative cost of public service output.

Between 1997 and 2007, the unit cost of public service output in total grew by 13.7 per cent more than unit costs for the whole economy, an annual average relative rise of 1.3 per cent.

In 2007, the unit cost of public service output rose by 0.6 per cent less than costs in general, the only time relative costs fell over the 10 year period.

The relative cost of public service output changes as a result of a combination of two factors:

- changes in the price of inputs used in the public service, such as pay rates for people employed and prices paid for the goods and services used as inputs. The aggregate price index for these inputs rose by 9.8 per cent more than prices in general for the whole economy between 1997 and 2007, an annual average rise of 0.9 per cent

- changes in the efficiency and effectiveness with which resources are used to produce the output. In other words, there is a change in productivity. Between 1997 and 2007, public service productivity fell by 3.4 per cent, meaning that the volume of input needed to produce a unit of output rose by an annual average of 0.3 per cent

These are experimental statistics and work continues to develop the measures.

\section{Introduction}

( NS publishes articles on public service productivity. Productivity is one measure of the way resources are used to produce public services. The ONS approach, based on a National Accounts framework and recommendations in the Atkinson Review (Atkinson 2005), compares 'output' from public services with 'inputs', and takes change in the quality of output and input into account, though this is difficult to measure.

This article is the first to use a new, but linked, measure: relative unit cost of public service output.

The relative unit cost measure looks at how much the cost of a unit of public service output, such as health procedures performed or pupils taught, both adjusted for quality, has changed compared to prices in general.

The relative unit cost of public service output changes for two reasons. Firstly, there may be a change in the price of inputs used in the public service, such as pay rates or prices of drugs or school books used. For this article, these pay and price changes are considered relative to the change in prices throughout the economy. Secondly, there may be a change in the way resources are combined to produce the output, for example, fewer staff hours to produce the same result: this is a change in productivity. Both issues are important in helping understand the way national resources are used to produce public services.
The relationship is:

Relative cost of output of public services $=$

Relative price of input into public services Productivity

and is discussed in more detail in

Annex A.

This article analyses changes in the relative unit cost of output of public services, using figures between 1997 and 2007, and shows the contributions to these changes from changes in the relative price of inputs into public services and from changes in productivity, for which figures were published previously as Total Public Service Output and Productivity (ONS 2009a).

The article is organised according to the following sections which aim to:

- summarise the estimates of relative unit cost of public service output

- outline the background to the article

- discuss cost per unit output of public services

- discuss input per unit output of public services

- discuss price per unit input of public services

- provide a comparison of components of relative unit cost of output of public services

- discuss the individual public service areas in detail

- provide a conclusion to the article

These are experimental statistics. ONS 
welcomes feedback on this new approach and will aim to update figures annually.

\section{Key messages}

This article presents the first estimates of the relative unit cost of public service output, a new experimental measure related to public service productivity. It is a measure of how much the cost of a unit of public service output, such as health procedures performed or pupils taught, has changed compared to prices in general: the relative unit cost of public service output. Figure 1 illustrates the cumulative change in relative unit cost since 1997.

Between 1997 and 2007 the key points to note are that:

- the volume of input needed to produce a unit of output grew by 3.5 per cent, an annual average rise of 0.3 per cent (this is the same as saying productivity fell by 0.3 per cent)

- the relative costs per unit of input grew by 9.8 per cent, an annual average rise of 0.9 per cent (this means input prices in the public services grew almost 1 per cent a year faster than prices in the whole economy)

- as a result of these effects, the relative cost of a unit of public service output grew by 13.7 per cent, an annual average rise of 1.3 per cent

Between 2006 and 2007:

- the index of the volume of inputs needed to produce a unit of output fell from 104.1 to 103.5 (a fall of 0.6 per cent, meaning that productivity rose)

- the index of the relative price per unit of input hardly changed, from 109.9 to 109.8

- the index of the relative cost of a unit of public service output fell from 114.4 to 113.7 (a fall of 0.6 per cent)

This contrasts with earlier years, when the relative unit cost of output rose. The rise in productivity in 2006 was insufficient to offset the rise in the relative price of inputs in that year.

Most of the rise in the relative unit costs of public service output comes from the rise in the relative price of inputs to public services, with a smaller fraction being explained by the fall in productivity.

This article also examines the changes in the relative unit cost of output, input per unit of output and relative price per unit of input by the major public service areas.
Key points to note are that:

- between 1997 and 2007 the relative unit cost of output did not fall in any public service

- in some service areas, notably healthcare, the relative unit cost of output fell in 2007

Labour costs grew faster in healthcare and education, where detailed information is more readily available, than in the wider economy in the later part of the period. This is shown in Figures 2 and 3.

The prices of the goods and services used as inputs into healthcare rose 10 per cent, less than home costs per unit of output ${ }^{1}$ in the wider economy, which grew by 28 per cent as illustrated in Figure 4.

\section{Background}

Public services are not normally traded in a market. In addition, units of output are not easy to define, so there is no

\section{Figure 1}

The change in total public service input per unit of output, relative price per unit of input and relative cost per unit of output, 1997-2007

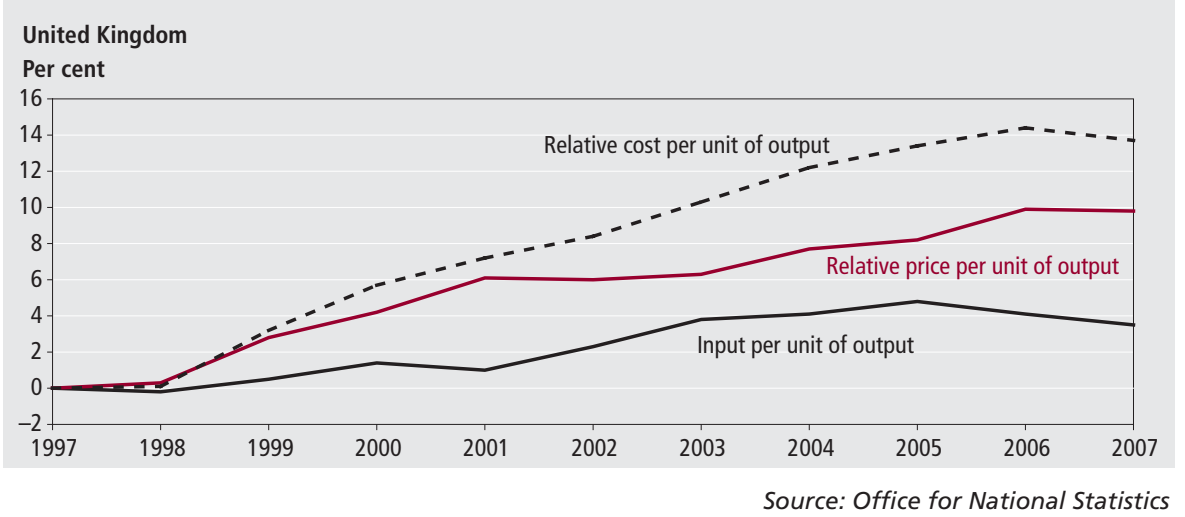

Figure 2

\section{Cumulative change in labour costs in healthcare and whole economy, 1997-2007}

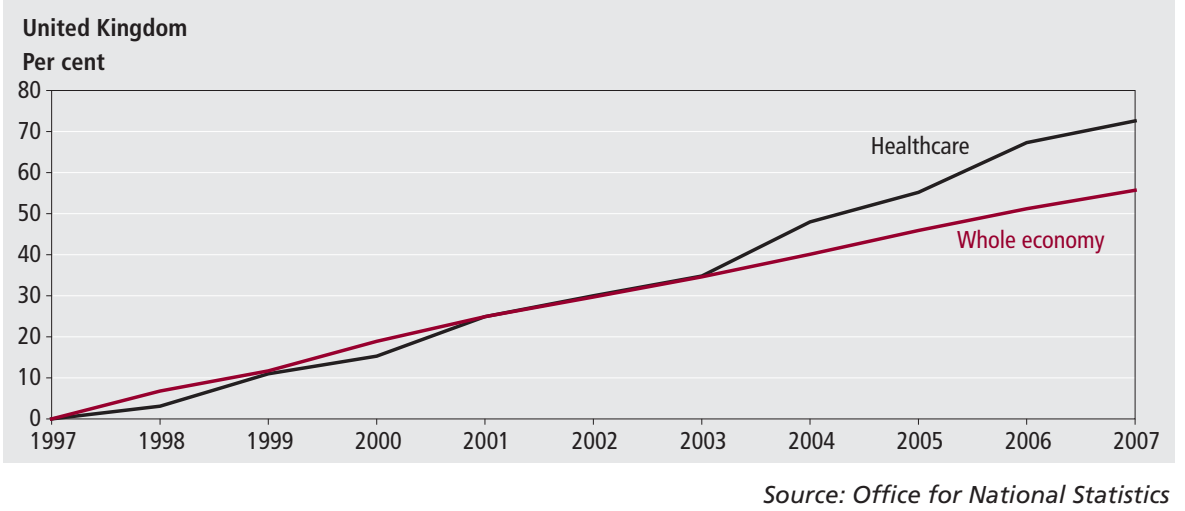

\section{Figure 3}

\section{Cumulative change in labour costs in education and whole economy,} 1997-2007

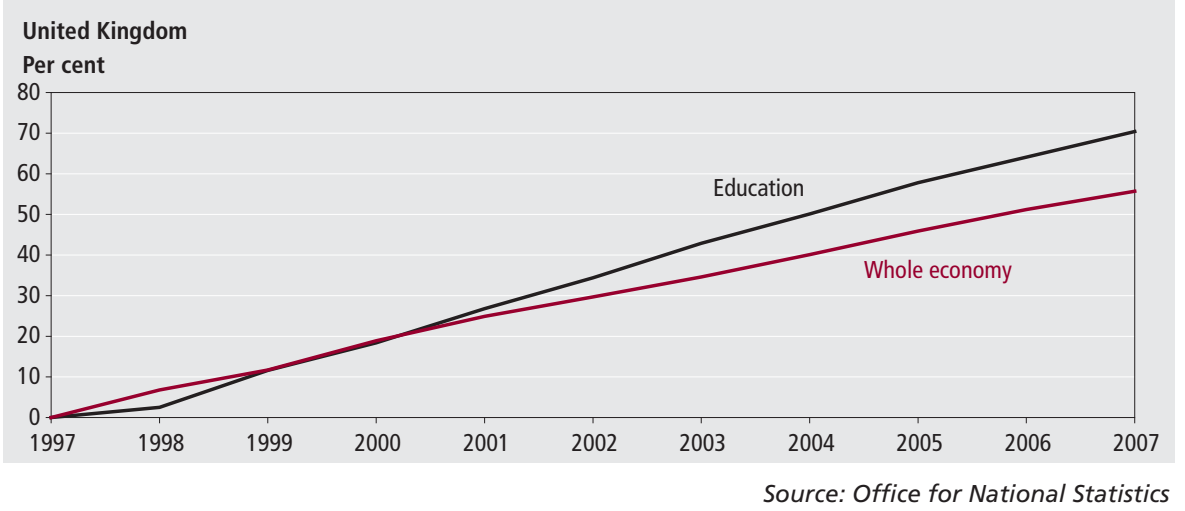




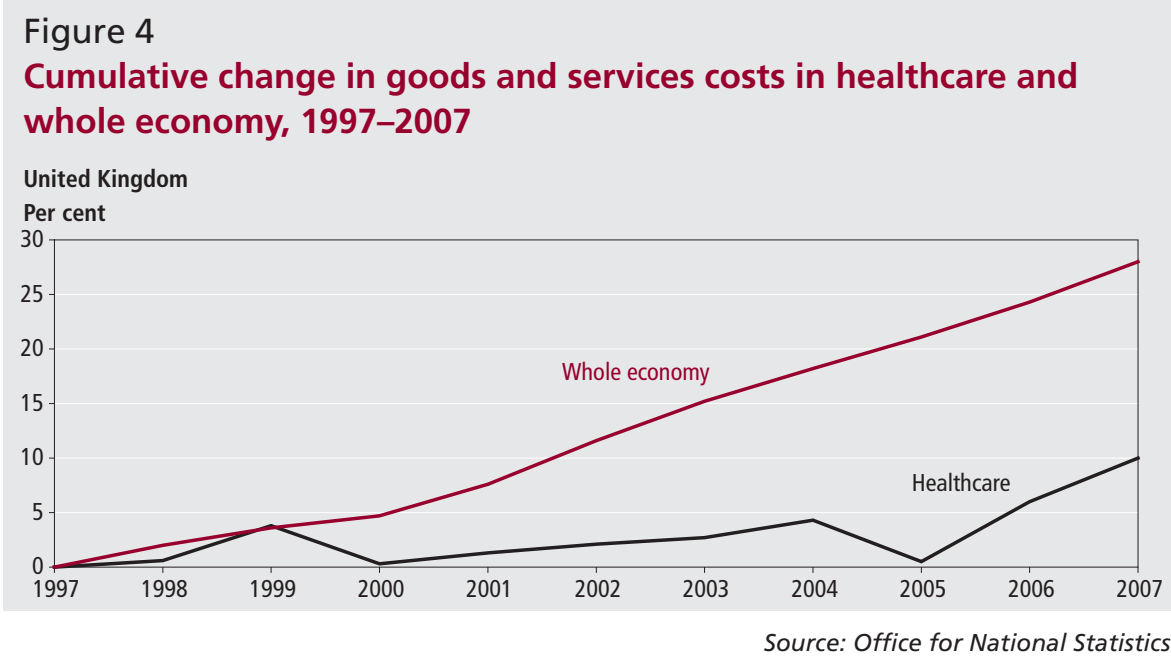

straightforward measure of the price of a unit of public service output. Before 1998 it was usual to estimate public service output by assuming that the output was simply equal to the inputs used. However, since 1998 ONS has published estimates of the output of public services using direct activity measures for many services, such as health procedures performed and pupil hours experienced.

Approximately 65 per cent of General Government Final Consumption Expenditure (GGFCE) is now covered by direct activity measures. The remainder, mainly services provided collectively to everyone, such as defence, continue to be measured by the 'output=inputs' convention.

Once output is measured independently of inputs, it becomes possible to calculate measures of output per unit of input (productivity). ONS has published a series of articles, most recently, Total Public Service Output and Productivity (ONS 2009a) measuring change in productivity in public services. It also becomes possible to calculate the implicit price of public service output by dividing total expenditure on public services by the volume of output. This gives an estimate of a deflator for GGFCE, what taxpayers pay for a unit of government output - the (money) cost of public service output. Movements in this deflator give an estimate of inflation in the price of public services. Although this was noted in Understanding Government Output and Productivity (Pritchard 2003), little attention has so far been given to this measure.

The issue of greatest relevance to taxpayers and users of government services is how this measure of public service inflation compares with inflation in general. This comparison is of direct interest in showing whether the cost of a unit of public service output is rising in line with overall inflation. It also demonstrates how much of other goods and services are being given up to acquire the given levels of public service output. There are several indices of general prices that could be used for this comparison. The one chosen for this article is the index of total home costs per unit of output published in United Kingdom National Accounts Blue Book 2008 (ONS 2008), which reflects factors such as total labour costs per unit of output. This comparison gives an indication of what goods and services might have been produced if the resources devoted to public service provision had been devoted to producing goods and services in the same mix by the whole economy. See Annex A for some further technical notes on the method.

The relative cost of a unit of output can be broken down into two parts (see Annex A) to give some insight into what lies behind the overall movement in relative cost. The first part is the volume of input required to produce a unit of output; the second part is the relative price of the inputs used.

The rise in the index of overall input prices can, in principle, grow faster (or slower) than prices in general for three reasons. Firstly, the prices paid for inputs common to both the public and private sectors may grow faster (or slower) within public service procurement. Secondly, public services may use a different input mix, that is they may use, per unit of output, more (or less) than the economywide average of those inputs whose prices are increasing fastest. For example, if public services are labour intensive relative to the economy as a whole, and real wages are increasing (therefore money wages rise faster than prices in general), then there will be a tendency for the public service relative input price index to increase, even if real wages in public services grow at the same rate as real wages in the whole economy. Thirdly, the share of the input whose price is growing fastest may change at a different rate between public and private sectors.

In practice it is not possible to completely separate public and private sector input prices using current methods. This is because the volume of inputs of goods and services is (with some notable exceptions such as the use of drugs in healthcare) estimated by deflating the identified categories of expenditure by a price index based on what happens to prices in that category across the whole economy, not just in public services. In contrast, labour input in public services is often estimated directly, and therefore it is possible - using available figures for total labour costs in public services - to work out the relevant public service labour costs per unit of input. These can be compared with movements in labour costs in the wider economy. Comparing shares of expenditure on the different types of inputs between public services and the market sector is also not straightforward. Public services form part of final expenditure, Gross Domestic Product (Expenditure) $(\mathrm{GDP}(\mathrm{E}))$ whereas industry shares are in terms of Gross Domestic Product (Output) $(\mathrm{GDP}(\mathrm{O}))$ and value-added.

The following sections provide estimates of cost per unit of public service output, input per unit of public service output (the reciprocal of productivity) and price per unit of public service input.

\section{Cost per unit of output}

How has cost per unit of overall public service output changed? We first consider the money cost per unit of public service output, the GGFCE deflator implied by the output estimates headlined in Total Public Service Output and Productivity (ONS 2009a). This gives a measure of inflation for public service output.

Figure 5 illustrates how this cost has risen since 1997.

Between 1997 and 2007 the key points to note are that:

- the cost per unit of output of public services grew by 45.5 per cent, an annual average increase of 3.8 per cent

- the cost rose in every year 


\section{Figure 5 \\ Cumulative change in total public service cost per unit of output, 1997-2007}

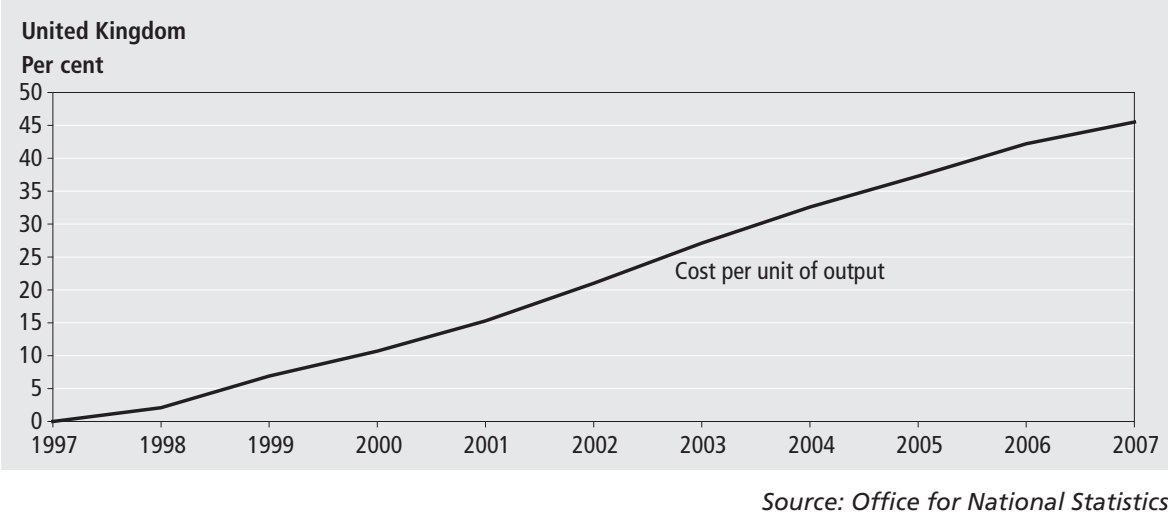

Figure 6

Growth in total public service cost per unit of output, 1998-2007

United Kingdom

Per cent

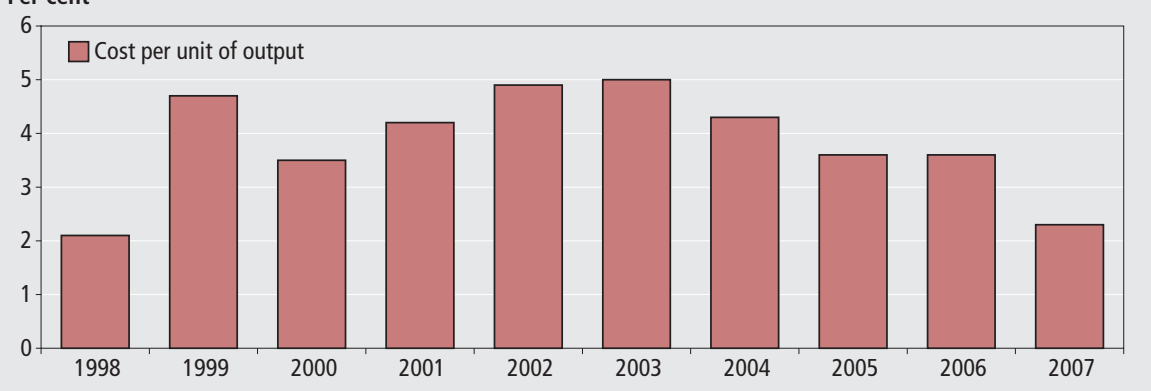

Source: Office for National Statistics

Figure 7

Cumulative change in relative unit cost of public service, 1997- 2007

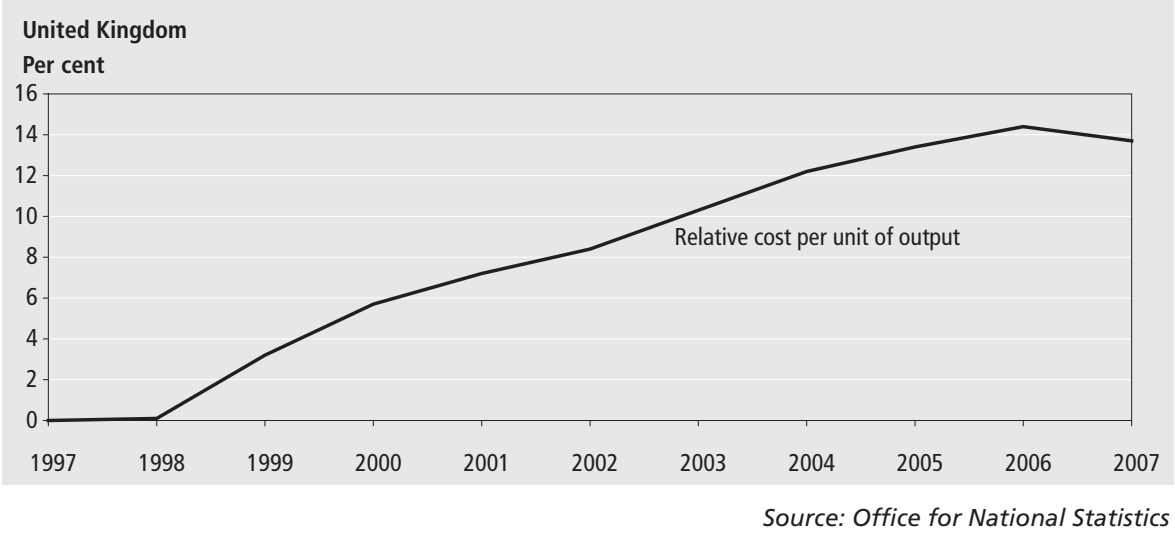

Figure 6 illustrates how unit cost changed year by year.

Key points to note are that:

- the increase in unit cost rose from 2.1 per cent in 1998 to 4.7 per cent in 1999

- the cost rise then moderated in 2000, followed by a steady rise in cost growth to a peak of 5.0 per cent in 2003

- from 2003 unit cost growth fell, reaching a low of 2.3 per cent in 2007

\section{Relative cost per unit output}

A more meaningful measure than money costs alone can be found by comparing the cost of public service output with an index of overall prices. Candidate indices include:

- the GDP (Expenditure) deflator, which measures changes in the price of all final spending in the economy, and thus includes the prices of imports as well as consumption and investment

- home costs per unit of output, which measures the cost of producing output in the UK

- consumer price indices such as the Retail Prices Index or the Consumer Prices Index

The most appropriate index of overall prices depends on what question is being asked. Dividing by the GDP(E) deflator measures what the resources used in obtaining public services could buy if spent on exactly the mix of goods and services currently bought at whole economy level. Dividing by home costs per unit of output approximates what the resources used in public services could produce if they were used in exactly the same mix as is produced by the whole economy. Dividing by a consumer prices index gives the consumption foregone by the provision of public services. Neither the Retail Prices Index (RPI) nor the Consumer Prices Index (CPI) cover the whole of consumers' expenditure, nor are they constructed as deflators comparable in construction to the GDP(E) deflator.

The main body of this article uses home costs per unit of output. Comparing public service costs per unit of output with total home costs per unit of output gives an indication of what could have been produced if the resources used in public services had instead been used to produce a mix of goods and services as produced within the economy as a whole ${ }^{2}$. It provides a measure of opportunity cost in terms of overall output foregone.

Figure 7 illustrates public service unit costs relative to home costs per unit of output for public services as a whole, henceforth referred to as 'the relative unit cost of public services'.

Between 1997 and 2007 the relative unit cost of public service output grew by 13.7 per cent, an annual average increase of 1.3 per cent. Of this 1.3 per cent, 0.3 percentage points, are explained by the rise in input per unit of output, and the remaining 1.0 percentage point by the rise in input prices in public services relative to the rise in home costs per unit of output.

Figure 8 gives the annual rates of change of the relative unit cost public services.

Key points to note are that:

- the relative unit costs barely changed from 1997 to 1998

- the relative unit costs increased particularly fast in 1999 and 2000, by 3.1 and 2.4 per cent respectively

- the growth in relative unit cost fell to 1.2 per cent in 2002 




Figure 9

\section{Cumulative change in total public service input per unit of output, 1997- 2007}

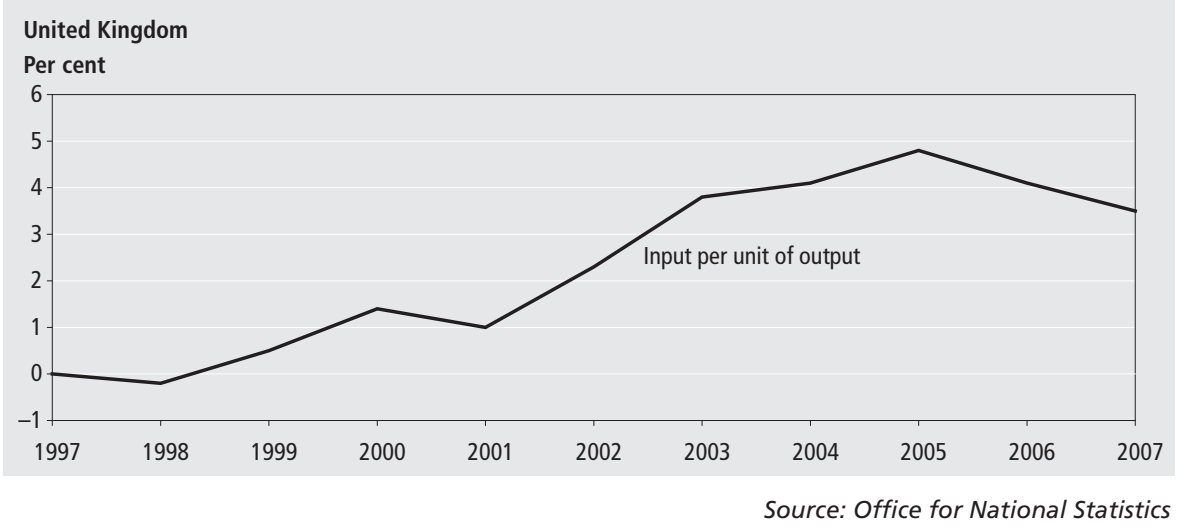

\section{Figure 10}

\section{Growth in total public service input per unit of output, 1998-2007}

\section{United Kingdom \\ Per cent}

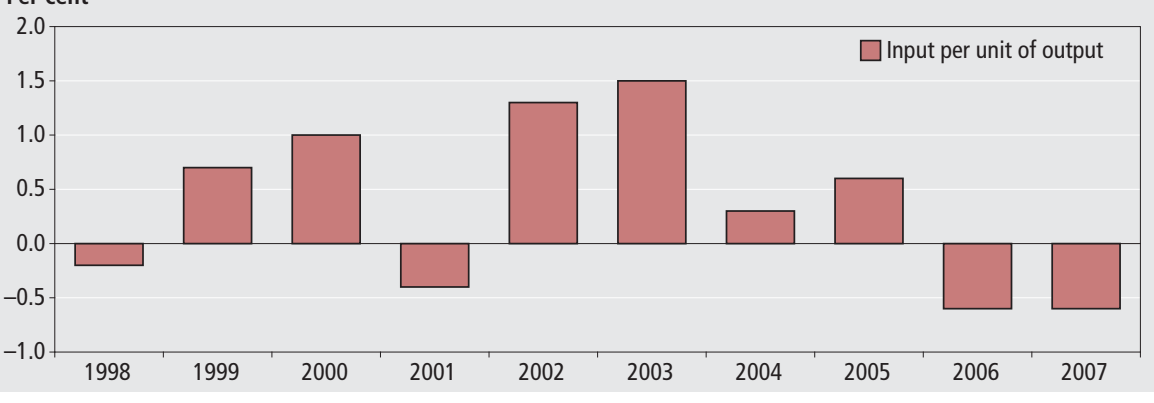

Source: Office for National Statistics

- the growth in relative unit cost rose again in 2003 to 1.7 per cent, where it remained in 2004

- after 2004 growth in relative unit cost slowed

- in 2007 the index fell by 0.6 per cent

\section{Input per unit of output}

How has overall input per unit of output changed?

This and the following sections outline the factors underlying the changes in

- input per unit of output grew by 3.5 per cent with annual average growth of 0.3 per cent

- the highest level of input per unit of output was reached in 2005, then it fell in 2006 and 2007

Figure 10 illustrates the annual rate of change of input per unit of output.

Key points to note are that:

- input per unit of output increased fastest (productivity fell) in the years 2002 and 2003

- in 2006 input per unit of output fell for the first time since 2001

- input per unit of output also fell in 2007 , that is productivity rose in the last two years

\section{Price per unit of input}

How has price per unit of input into public service changed overall?

The other component of relative unit cost of output is the cost of the input required to produce it. This section considers this cost, that is an expenditure weighted average of the price indices for labour, goods and services and capital, used in public services. The first section considers movements in an index of money costs of inputs. The second section constructs an index of relative input costs, that is comparing movements in money costs with the movements in total home costs per unit of output in the wider economy.

Figure 11 illustrates (money) price per unit of input for total public service output $^{3}$.

Between 1997 and 2007 the key point to note is that:

- the input price index increased by 40.6 per cent, an annual average increase of 3.5 per cent

Figure 12 illustrates the annual rate of change of input prices.

Key points to note are that:

- the highest growth in input prices was in 2001 , when they grew by 4.6 per cent

- in 2002 and 2003, input growth remained relatively high, at 3.6 and 3.5 per cent a year respectively, before rising again to 4.0 per cent in 2004

- although the growth weakened in 2005 to 2.9 per cent, it rose in 2006 to 4.2 per cent, the second highest growth rate within the period 1998 to 2007
- growth in input prices slowed to 3.0 per cent in 2007 


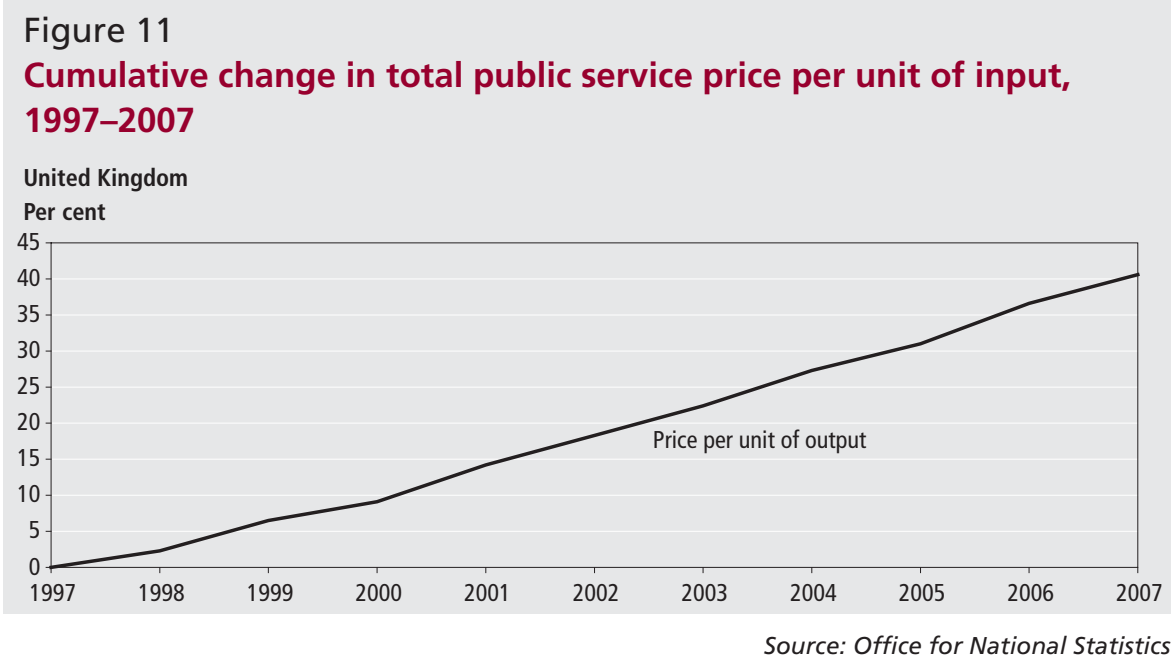

Figure 12

Growth in total public service price per unit of input, 1998-2007

United Kingdom

Per cent

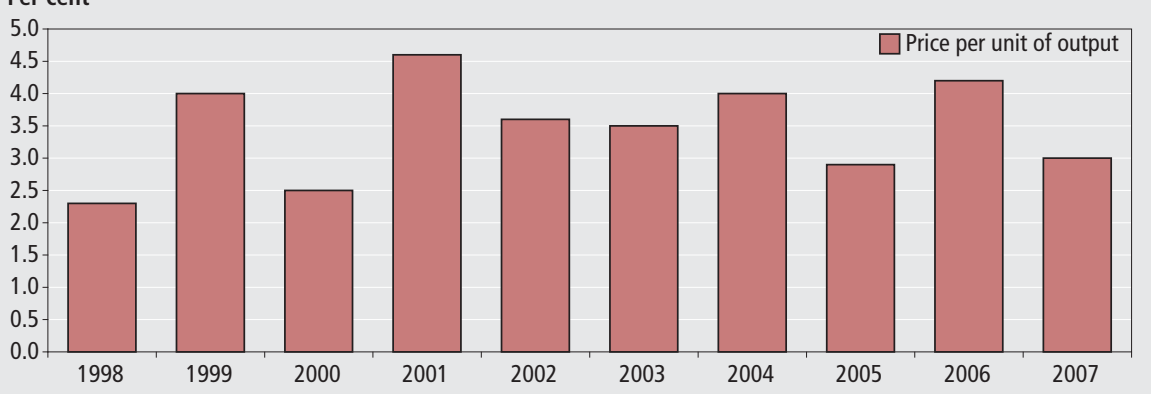

Source: Office for National Statistics

Figure 13

\section{Cumulative change in total public service relative price per unit of input, 1997-2007}

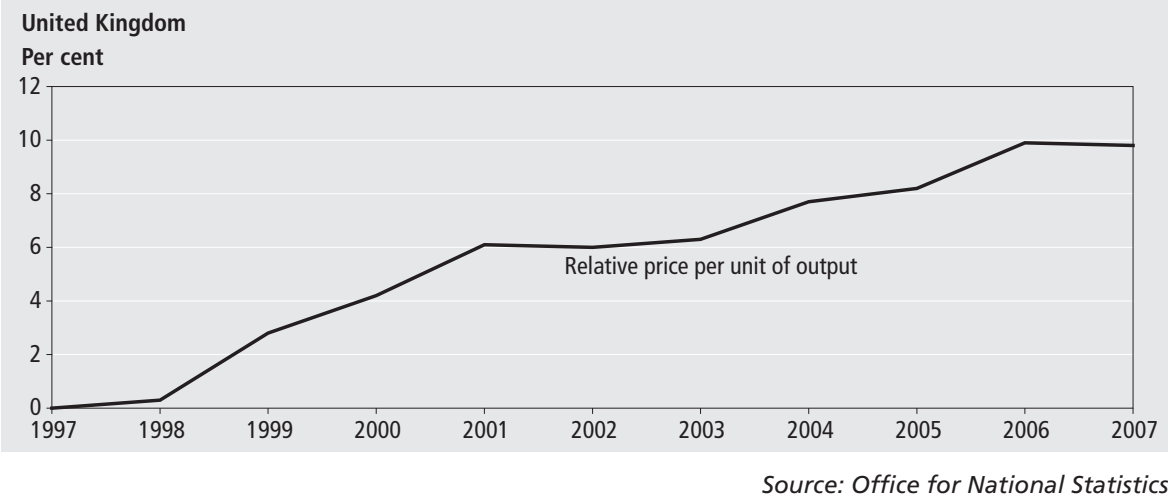

How has price per unit of input risen in comparison to prices in general? The previous section considered changes in actual prices. A comparison with price changes in general is needed to construct the component of relative unit cost of output.

Figure 13 therefore illustrates the relative price per unit of input, which compares the rise in the prices of inputs with the rise in prices in general, as measured by the index of total home costs per unit of output. note is that:

- the cost index increased by 9.8 per cent, an annual average increase of 0.9 per cent

In addition:

- relative input costs rose by almost six per cent between 1998 and 2001

- from 2001 to 2003 relative input prices changed little
Between 1997 and 2007 the key point to
- from 2003 to 2006 relative input prices rose, to 9.9 per cent above the 1997 level

- relative input costs fell very slightly in 2007

\section{Comparison of components of relative cost of output}

Figure 14 brings together the indices of change in the overall relative cost per unit of output and in its components, input per unit of output and the relative price per unit of input.

Between 1997 and 2007 the relative unit cost of public service output rose. The major part of this rise was due to the rise in the index of input prices. However the rise, over the whole period, in input requirements (that is, the fall in productivity) also made some contribution.

The relative unit cost of output fell in 2007. This arose from a fall in both relative input prices (that is, public service input prices rose less than home costs per unit of output) and in input requirements. The fall in input requirements (rise in productivity), however, was the dominant effect.

\section{Individual public service areas}

So far this article has only considered public services as a whole. This section initially examines unit cost, both absolute and relative, of public service by broadly classified 'Classification of the Functions of Government' (COFOG) and continues by examining the behaviour of the component parts of the relative unit cost index: input per unit of output and the relative price of inputs. This section concludes by looking at the two largest spending areas, healthcare and education, in more detail to see how the prices of the different kinds of inputs to health and education have been moving against relevant comparators.

How has cost per unit of output varied by service area?

Table 1 summarises the index of cost per unit of output by service area ${ }^{4}$.

Between 1997 and 2007 the key points to note are that:

- the annual average cost per unit of output increased the most in children's social care, 6.1 per cent

- public order and safety (POS) exhibited the second highest growth in annual average cost per unit of output at, 5.8 per cent 


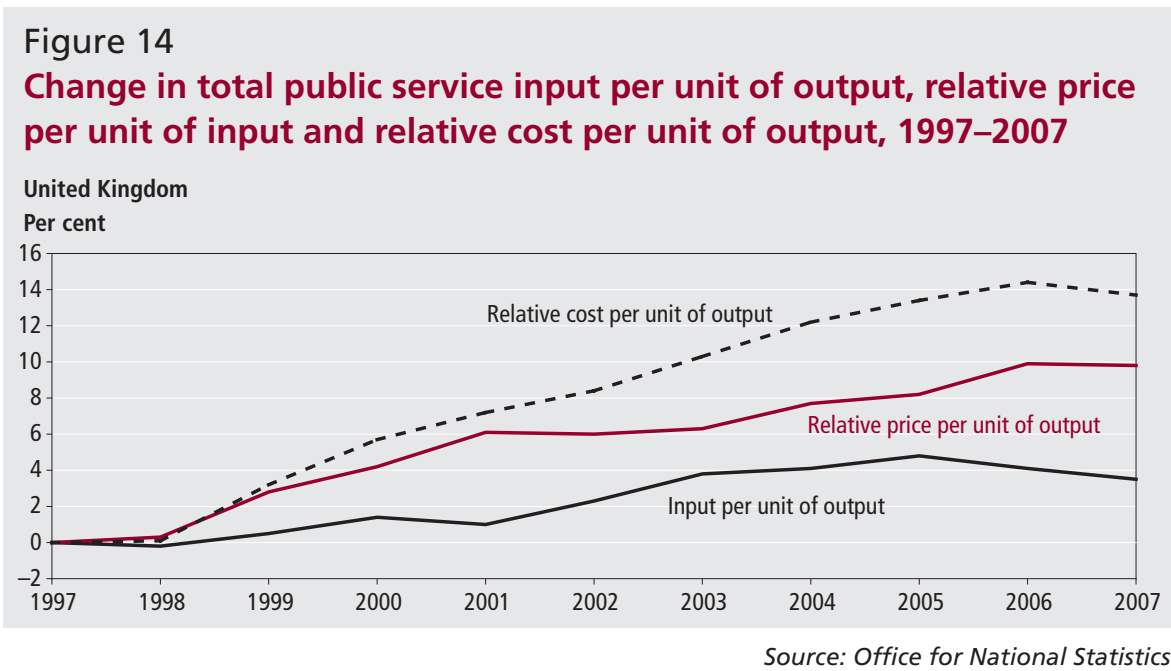

- adult social care (ASC) exhibited an average growth in cost per unit of output of 5.5 per cent

- the average cost per unit of output of police was 4.9 per cent a year and in 'other' was 4.3 per cent ${ }^{5}$

- the average cost per unit of output of healthcare grew by 3.8 per cent, the same as the increase in unit costs for public services as a whole. The lower than public service average increase in input prices offset the somewhat higher than public service average increase in input per unit of output to give an average overall performance in terms of cost per unit of output

- the average cost per unit of output of defence rose by 2.5 per cent ${ }^{5}$

- social security administration (SSA) experienced the lowest increase in cost per unit of output of the directly measured services. The fall in input per unit of output, together with an only slightly above average rise in input costs, ensured that cost per unit of output growth was well below the average for all services

The large increases in relative unit costs in children's and adult social care and in public order and safety in part reflect the inadequacies of the output measures, which do not take proper account of quality (ONS 2009a).

Table 2 summarises public service unit costs relative to home costs per unit of output for each individual public service area

Between 1997 and 2007 key points to note are that:

- the absolute differences between services are the same as for the growth of (money) costs per unit of output

- all services, with the exception of defence, experienced a marked rise in relative unit cost

Table 1

Public service cost per unit of output by service area, 1997-2007

Index $(1997=100)$

\begin{tabular}{|c|c|c|c|c|c|c|c|c|c|c|c|c|}
\hline & & & & & & & & & & & & $\begin{array}{r}\text { Average } \\
\text { annual } \\
\text { percentage }\end{array}$ \\
\hline & 1997 & 1998 & 1999 & 2000 & 2001 & 2002 & 2003 & 2004 & 2005 & 2006 & 2007 & change \\
\hline Healthcare & 100.0 & 102.8 & 108.0 & 109.7 & 113.5 & 119.4 & 124.7 & 131.9 & 134.3 & 142.2 & 145.5 & 3.8 \\
\hline Education & 100.0 & 100.8 & 104.2 & 109.6 & 118.7 & 128.4 & 135.1 & 141.6 & 147.6 & 153.8 & 159.2 & 4.8 \\
\hline Adult social care & 100.0 & 103.0 & 111.7 & 119.9 & 125.4 & 131.2 & 144.5 & 148.2 & 158.7 & 165.4 & 170.1 & 5.5 \\
\hline Social security admin & 100.0 & 98.1 & 111.4 & 124.0 & 116.9 & 118.0 & 149.6 & 145.7 & 171.5 & 133.2 & 129.2 & 2.6 \\
\hline Children social care & 100.0 & 105.4 & 113.9 & 119.2 & 127.5 & 135.1 & 144.5 & 152.5 & 161.4 & 174.6 & 181.1 & 6.1 \\
\hline Public order \& safety & 100.0 & 106.2 & 125.1 & 139.5 & 136.8 & 143.3 & 150.8 & 168.3 & 173.8 & 175.0 & 175.4 & 5.8 \\
\hline Police & 100.0 & 104.4 & 110.1 & 114.9 & 130.4 & 138.7 & 142.4 & 146.4 & 151.7 & 157.0 & 161.2 & 4.9 \\
\hline Defence & 100.0 & 100.2 & 102.4 & 105.2 & 108.2 & 110.8 & 114.9 & 118.3 & 123.8 & 127.5 & 128.0 & 2.5 \\
\hline Other & 100.0 & 102.6 & 107.4 & 111.7 & 116.7 & 123.2 & 130.4 & 136.4 & 143.0 & 149.7 & 152.9 & 4.3 \\
\hline Total & 100.0 & 102.1 & 106.9 & 110.7 & 115.3 & 121.0 & 127.1 & 132.6 & 137.3 & 142.2 & 145.5 & 3.8 \\
\hline
\end{tabular}

Source: Office for National Statistics

Table 2

Relative cost per unit of output by service area, 1997-2007

\begin{tabular}{|c|c|c|c|c|c|c|c|c|c|c|c|c|}
\hline & & & & & & & & & & & & $\begin{array}{r}\text { Average } \\
\text { annual } \\
\text { percentage }\end{array}$ \\
\hline & 1997 & 1998 & 1999 & 2000 & 2001 & 2002 & 2003 & 2004 & 2005 & 2006 & 2007 & change \\
\hline Healthcare & 100.0 & 100.8 & 104.3 & 104.8 & 105.4 & 106.9 & 108.2 & 111.6 & 110.9 & 114.4 & 113.4 & 1.3 \\
\hline Education & 100.0 & 98.8 & 100.6 & 104.6 & 110.3 & 115.0 & 117.3 & 119.8 & 121.9 & 123.8 & 124.4 & 2.2 \\
\hline Adult social care & 100.0 & 101.0 & 107.9 & 114.5 & 116.5 & 117.5 & 125.5 & 125.4 & 131.0 & 133.1 & 132.9 & 2.9 \\
\hline Social security admin & 100.0 & 96.2 & 107.5 & 118.5 & 108.7 & 105.7 & 129.9 & 123.3 & 141.7 & 107.2 & 100.9 & 0.1 \\
\hline Children social care & 100.0 & 103.3 & 109.9 & 113.8 & 118.5 & 121.1 & 125.4 & 128.0 & 133.2 & 140.5 & 141.5 & 3.5 \\
\hline Public order \& safety & 100.0 & 104.2 & 120.7 & 133.3 & 127.1 & 128.4 & 130.9 & 142.4 & 143.5 & 140.8 & 137.1 & 3.2 \\
\hline Police & 100.0 & 102.3 & 106.2 & 109.7 & 121.2 & 124.2 & 123.6 & 123.8 & 125.3 & 126.3 & 125.9 & 2.3 \\
\hline Defence & 100.0 & 98.2 & 98.8 & 100.4 & 100.6 & 99.3 & 99.7 & 100.1 & 102.2 & 102.6 & 100.0 & 0.0 \\
\hline Other & 100.0 & 100.6 & 103.7 & 106.7 & 108.4 & 110.4 & 113.2 & 115.4 & 118.1 & 120.4 & 119.5 & 1.8 \\
\hline Total & 100.0 & 100.1 & 103.2 & 105.7 & 107.2 & 108.4 & 110.3 & 112.2 & 113.4 & 114.4 & 113.7 & 1.3 \\
\hline
\end{tabular}


Table 3

Public service input per unit of output by service, 1997-2007

\begin{tabular}{|c|c|c|c|c|c|c|c|c|c|c|c|c|}
\hline & & & & & & & & & & & & $\begin{array}{r}\text { Average } \\
\text { annual } \\
\text { rcentage }\end{array}$ \\
\hline & 1997 & 1998 & 1999 & 2000 & 2001 & 2002 & 2003 & 2004 & 2005 & 2006 & 2007 & change \\
\hline Healthcare & 100.0 & 101.0 & 101.0 & 102.2 & 100.9 & 103.5 & 105.6 & 105.8 & 106.5 & 105.7 & 104.5 & 0.4 \\
\hline Education & 100.0 & 98.2 & 96.4 & 96.5 & 98.3 & 100.1 & 100.6 & 102.2 & 103.3 & 103.8 & 104.5 & 0.4 \\
\hline Adult social care & 100.0 & 98.4 & 102.4 & 103.6 & 104.3 & 104.8 & 109.6 & 106.0 & 107.1 & 106.6 & 104.5 & 0.4 \\
\hline Social security admin & 100.0 & 93.1 & 102.0 & 110.1 & 99.8 & 98.3 & 119.5 & 112.2 & 118.6 & 97.4 & 90.7 & -1.0 \\
\hline Children social care & 100.0 & 101.7 & 106.6 & 106.9 & 110.5 & 113.6 & 117.6 & 118.8 & 120.3 & 127.0 & 126.4 & 2.4 \\
\hline Public order \& safety & 100.0 & 100.5 & 114.1 & 123.1 & 115.9 & 118.6 & 119.4 & 128.3 & 128.2 & 123.0 & 119.9 & 1.8 \\
\hline Police & 100.0 & 100.0 & 100.0 & 100.0 & 100.0 & 100.0 & 100.0 & 100.0 & 100.0 & 100.0 & 100.0 & 0.0 \\
\hline Defence & 100.0 & 100.0 & 100.0 & 100.0 & 100.0 & 100.0 & 100.0 & 100.0 & 100.0 & 100.0 & 100.0 & 0.0 \\
\hline Other & 100.0 & 100.0 & 100.0 & 100.0 & 100.0 & 100.0 & 100.0 & 100.0 & 100.0 & 100.0 & 100.0 & 0.0 \\
\hline Total & 100.0 & 99.8 & 100.5 & 101.4 & 101.0 & 102.3 & 103.8 & 104.1 & 104.8 & 104.1 & 103.5 & 0.3 \\
\hline
\end{tabular}

\section{Table 4}

\section{Relative price per unit of input by public service, 1997-2007}

\begin{tabular}{|c|c|c|c|c|c|c|c|c|c|c|c|c|}
\hline & & & & & & & & & & & & $\begin{array}{r}\text { Average } \\
\text { annual } \\
\text { percentage }\end{array}$ \\
\hline & 1997 & 1998 & 1999 & 2000 & 2001 & 2002 & 2003 & 2004 & 2005 & 2006 & 2007 & change \\
\hline Healthcare & 100.0 & 99.7 & 103.2 & 102.6 & 104.5 & 103.3 & 102.5 & 105.5 & 104.2 & 108.2 & 108.8 & 0.8 \\
\hline Education & 100.0 & 100.6 & 104.3 & 108.4 & 112.2 & 114.9 & 116.6 & 117.3 & 118.0 & 119.2 & 119.1 & 1.8 \\
\hline Adult social care & 100.0 & 102.6 & 105.3 & 110.5 & 111.7 & 112.2 & 114.5 & 118.3 & 122.3 & 124.8 & 127.2 & 2.4 \\
\hline Social security admin & 100.0 & 103.3 & 105.4 & 107.6 & 109.0 & 107.5 & 108.7 & 109.9 & 119.4 & 110.0 & 111.3 & 1.1 \\
\hline Children social care & 100.0 & 101.6 & 103.1 & 106.5 & 107.3 & 106.6 & 106.7 & 108.5 & 110.8 & 110.6 & 111.9 & 1.1 \\
\hline Public order \& safety & 100.0 & 103.6 & 105.8 & 108.2 & 109.7 & 108.3 & 109.7 & 111.0 & 111.9 & 114.5 & 114.3 & 1.3 \\
\hline Police & 100.0 & 102.3 & 106.2 & 109.7 & 121.2 & 124.2 & 123.6 & 123.8 & 125.3 & 126.3 & 125.9 & 2.3 \\
\hline Defence & 100.0 & 98.2 & 98.8 & 100.4 & 100.6 & 99.3 & 99.7 & 100.1 & 102.2 & 102.6 & 100.0 & 0.0 \\
\hline Other & 100.0 & 100.6 & 103.7 & 106.7 & 108.4 & 110.4 & 113.2 & 115.4 & 118.1 & 120.4 & 119.5 & 1.8 \\
\hline Total & 100.0 & 100.3 & 102.8 & 104.2 & 106.1 & 106.0 & 106.3 & 107.7 & 108.2 & 109.9 & 109.8 & 0.9 \\
\hline
\end{tabular}

- the rise in children's social care (CSC) was the highest

- healthcare experienced the average rise for public services as a whole

- only defence and SSA had increases in relative unit cost below the public service average

- the relative unit cost of SSA rose by only 0.1 per cent a year and relative unit costs in defence were virtually unchanged - that is, a unit of output cost the same in terms of output foregone in 2007 as in 1997

How has input per unit of output moved in different services? Input per unit of output (the reciprocal of productivity) has not moved uniformly across all public services. Table 3 illustrates growth in input per unit of output by individual service between 1997 and 2007.

Between 1997 and 2007 the input per unit of output in:

- CSC grew fastest, by 26.4 per cent overall, an annual average increase of 2.4 per cent
- POS grew by 19.9 per cent, an annual average growth of 1.8 per cent, the second fastest growth

- ASC grew by 4.5 per cent, an annual average growth of 0.4 per cent

- healthcare grew by 4.5 per cent, an annual average growth of 0.4 per cent

- education grew by 4.5 per cent, an annul average growth of 0.4 per cent

- SSA fell by 9.3 per cent, an annual average fall of 1.0 per cent (SSA was the only service where input per unit of output fell)

The remaining services, police, defence and 'other', provide services collectively for everyone rather than directly to individuals. Here, following international guidance, output is assumed to be equal to inputs. So input per unit of output is unchanged by assumption.

Due to the absence of quality adjustments, the estimates of input per unit of output of CSC and POS may be too high since the productivity growth is underestimated (ONS 2009a).
How has relative price per unit of input varied by service?

Table 4 summarises the relative price per unit of input by individual public service.

Between 1997 and 2007 the relative price per unit input:

- grew above the average annual rate of 0.9 per cent in every sector except healthcare, where relative input prices grew by 0.8 per cent and defence, where relative input prices were unchanged

- increased the most in adult social care, where relative input prices grew by 27.2 per cent, an annual average of 2.4 per cent

More detailed discussion of major service areas

The following sections discuss the two largest spending areas, healthcare and education, in more detail. For these two services it has been possible to investigate what lies behind the input prices, in particular, in more depth. Future articles will extend this type of analysis to other public service areas. 


\section{Figure 15 \\ Cumulative change in healthcare input per unit of output, relative price per unit of input and relative cost per unit of output estimates, 1997-2007}

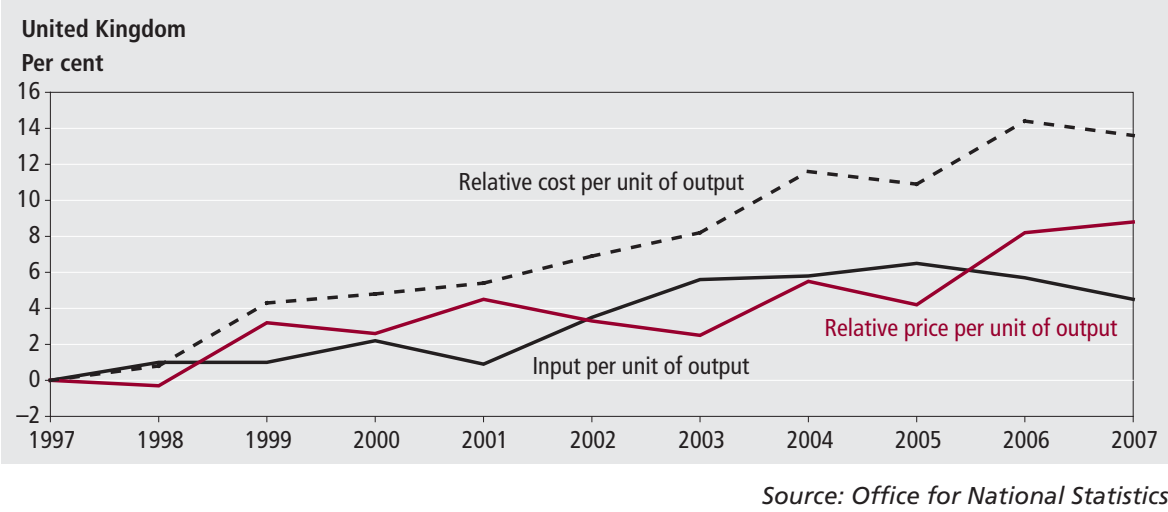

Figure 16

\section{Cumulative change in labour costs in healthcare and whole economy,} 1997-2007

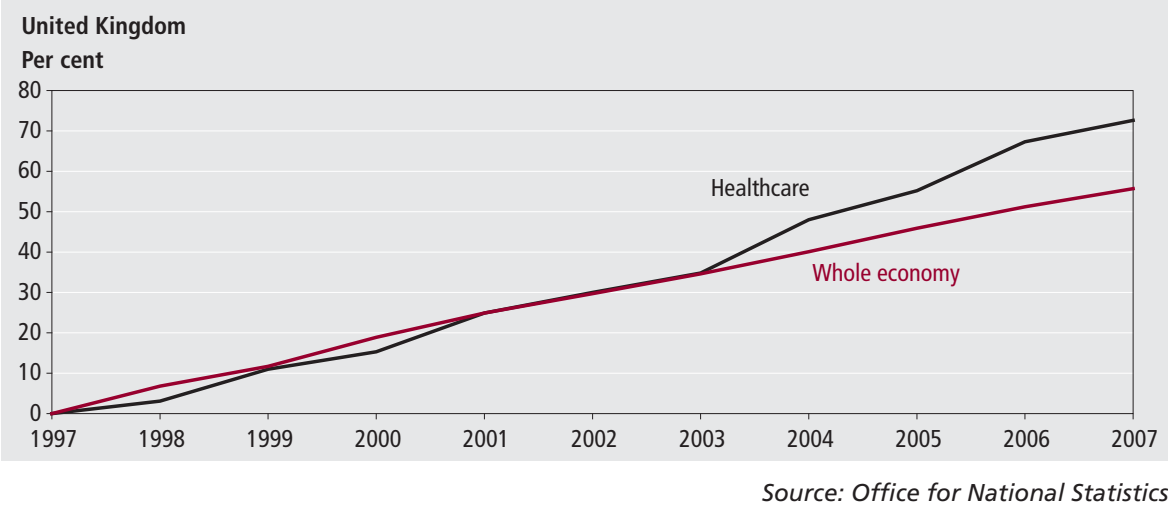

Figure 17

\section{Growth rates of labour costs for healthcare and whole economy, 1998-2007}

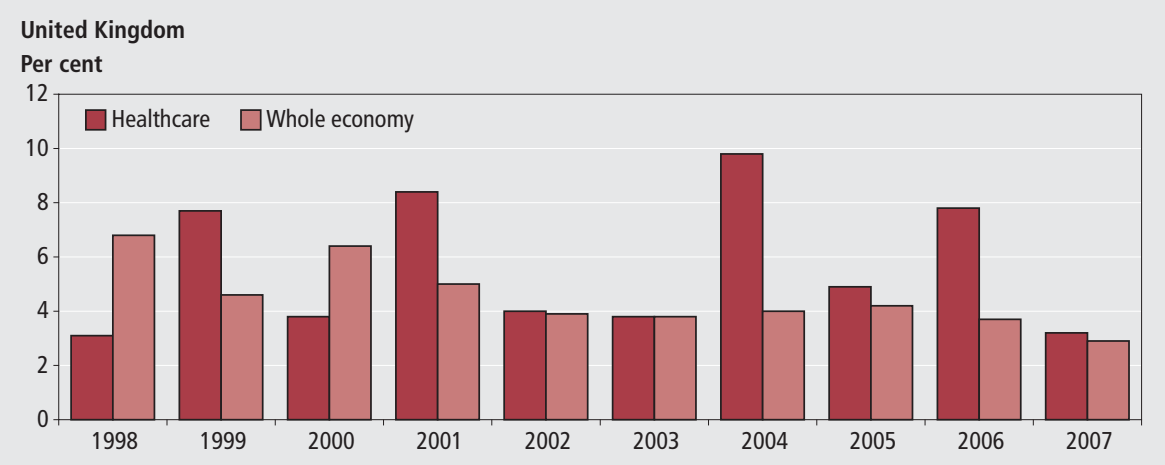

Source: Office for National Statistic

\section{Healthcare}

Healthcare accounts for approximately 30 per cent of total government spending on public services, the largest individual spending area. Figure 15 brings together the main comparisons for healthcare.

Between 1997 and 2007 key points to note are that:

- the relative costs per unit of output rose by 13.6 per cent, an annual average increase of 1.3 per cent

- relative input prices rose by 8.8 per cent, an annual average increase of 0.8 per cent

- input per unit of output rose by 4.5 per cent, an annual average increase of 0.4 per cent (equivalent to a fall in productivity of 0.4 per cent)

- relative unit costs rose in every year except 2005 and 2007
- in 2005 the fall in the input price index outweighed the slight rise in the index of input per unit of output

- in 2007 the opposite effect occurred, the fall in input requirements more than offset the rise in input prices

- between 2001 and 2003 the fall in input prices was offset by increasing input requirements, so relative unit costs rose

Although the relative input price index for healthcare rose over the whole period, implying that input prices increased faster than whole economy costs per unit of output, the rise in relative input prices in healthcare was below the rise in relative input prices for public services as a whole.

It is possible to investigate the reasons for rising relative healthcare input prices in more detail, by looking at the rise in the component parts of the healthcare input price index.

The shares of expenditure on these broad input categories of labour costs, costs of the inputs of goods and services and capital costs ${ }^{6}$ are summarised in Table 5.

Expenditure shares of each component do not change substantially over the period. The largest component of healthcare expenditure is labour, followed by goods and services, with capital being notably smaller. Using the theoretically more appropriate measure of capital services would raise the share of capital a little, as it also includes a real rental element, but this effect would not be large. So attention below is concentrated on labour and goods and services.

The prices of these component parts of the index can be compared with measures of relevant economy-wide prices or costs.

Figure 16 illustrates the index of labour costs in healthcare compared with the index of total compensation of employees per hour for the whole economy. Note that for both series, labour costs are not the same as current wage costs, as they include, for example, pension and other contributions.

Key points to note are that:

- labour costs in healthcare have risen faster than those in the whole economy, with most of the divergence occurring after 2003

- between 2001 and 2003 the index of healthcare labour costs was approximately at the same level as whole economy labour costs

- from 2004 to 2007 labour costs in 
Table 5

The expenditure share of each component of healthcare, 1997-2007

United Kingdom

\begin{tabular}{|c|c|c|c|c|c|c|c|c|c|c|c|}
\hline \multirow[t]{2}{*}{ United Kingdom } & \multirow[b]{2}{*}{1997} & \multirow[b]{2}{*}{1998} & \multirow[b]{2}{*}{1999} & \multirow[b]{2}{*}{2000} & \multirow[b]{2}{*}{2001} & \multirow[b]{2}{*}{2002} & \multirow[b]{2}{*}{2003} & \multirow[b]{2}{*}{2004} & \multirow[b]{2}{*}{2005} & \multicolumn{2}{|c|}{ Per cent } \\
\hline & & & & & & & & & & 2006 & 2007 \\
\hline Labour & 51.6 & 50.6 & 51.4 & 51.6 & 53.2 & 53.0 & 52.5 & 54.5 & 55.3 & 54.5 & 53.6 \\
\hline Goods and services & 45.2 & 46.3 & 45.7 & 45.4 & 44.2 & 44.5 & 44.9 & 43.3 & 42.5 & 43.4 & 44.4 \\
\hline Capital & 3.2 & 3.1 & 2.8 & 3.0 & 2.7 & 2.6 & 2.6 & 2.2 & 2.2 & 2.1 & 2.0 \\
\hline Total & 100.0 & 100.0 & 100.0 & 100.0 & 100.0 & 100.0 & 100.0 & 100.0 & 100.0 & 100.0 & 100.0 \\
\hline
\end{tabular}

Source: Office for National Statistics

Figure 18

Cumulative change in goods and services costs in healthcare and whole economy, 1997-2007

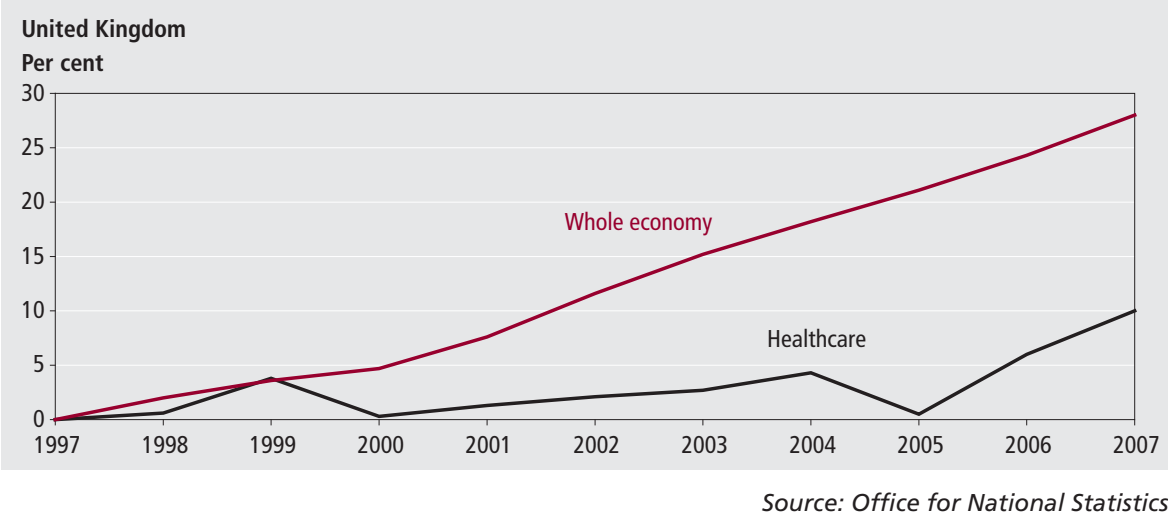

Figure 19

\section{Growth rates of goods and services costs for healthcare and whole economy, 1998-2007}

United Kingdom

\section{Per cent}

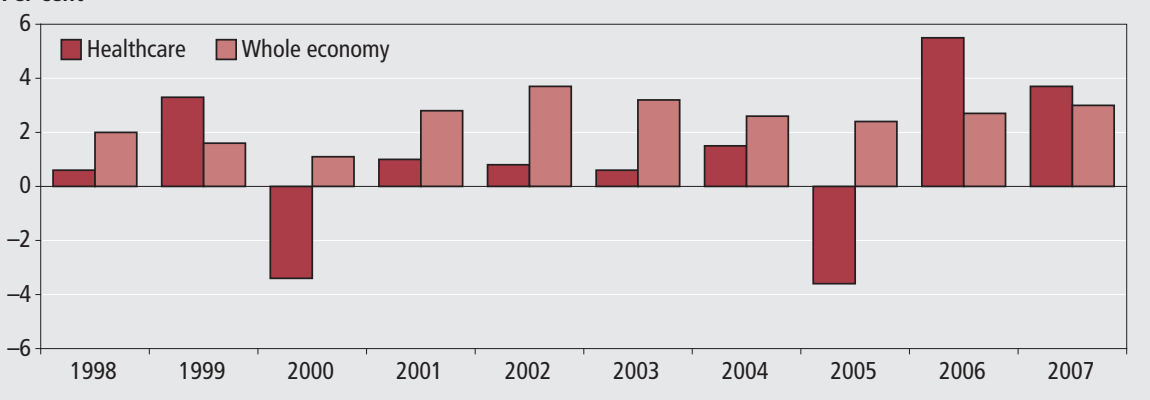

Source: Office for National Statistics

Figure 20

Cumulative change in education input per unit of output, relative price per unit of input and relative cost per unit of output estimates, 1997-2007

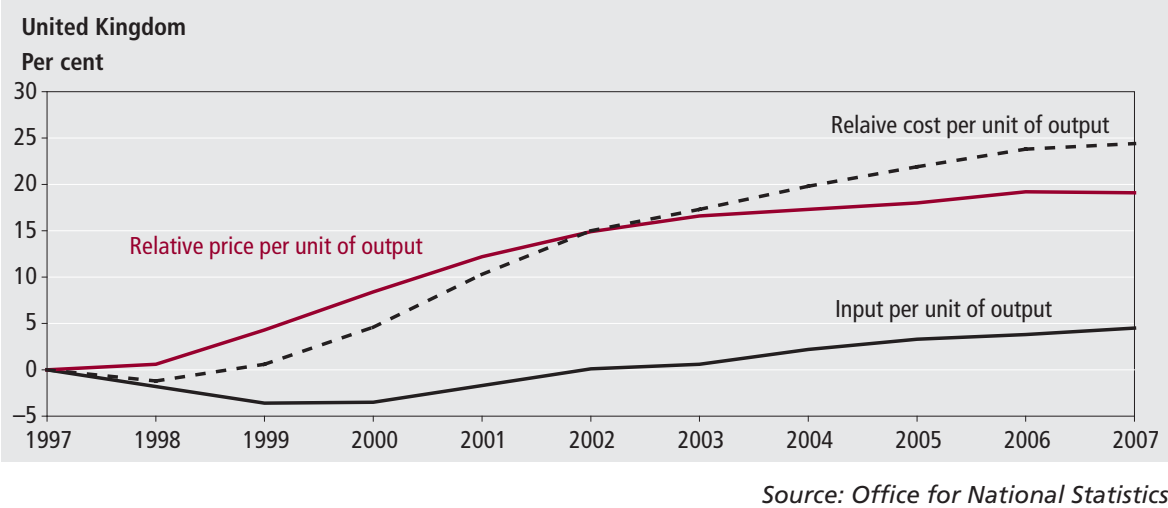

healthcare increased relative to labour costs in the economy as a whole (especially in 2004 and 2006). The result was that the healthcare index in 2007 stood 72.6 per cent above its 1997 level, whereas the whole economy index only stood 55.7 per cent above the 1997 level

Since labour costs account for over half of total healthcare input costs, the rise in labour costs within healthcare account for a substantial part of the rise in overall relative price of inputs. This is partly explained by new contractual arrangements, which were intended to encourage recruitment, improve incentives and reduce what were thought to be excessive hours worked in some parts of healthcare, hence improving quality of care. Some of the ways in which quality might improve may not be adequately accounted for by the quality adjustments made to derive output estimates.

Figure 17 illustrates the year-byyear movement of labour costs in both healthcare and the whole economy.

Healthcare labour costs grew more slowly than whole economy labour costs in 1998 and 2000, but rose faster in 1999 and 2001. As a result, in 2001 the index of healthcare labour costs and the whole economy labour costs were at the same level. In 2002 and 2003 the growth of labour costs in healthcare was the same as that in the economy as a whole. From 2004 to 2007 labour costs in healthcare increased relative to labour costs in the economy as a whole (especially in 2004 and 2006).

It is possible to compare labour costs within publicly funded healthcare directly with labour costs in the wider economy. However, it is not possible at present to make an analogous comparison for goods and services used in healthcare. This is because the estimates of the volume of inputs are generally made simply by deflating expenditure by appropriate whole economy price indices. The exception to this is drugs used as inputs that, like labour, are directly measured. However, it 
Table 6

The expenditure share of each component of education, 1997-2007

United Kingdom

\begin{tabular}{lrrrrrrrrrrr}
\hline & 1997 & $\mathbf{1 9 9 8}$ & $\mathbf{1 9 9 9}$ & $\mathbf{2 0 0 0}$ & $\mathbf{2 0 0 1}$ & $\mathbf{2 0 0 2}$ & $\mathbf{2 0 0 3}$ & $\mathbf{2 0 0 4}$ & $\mathbf{2 0 0 5}$ & $\mathbf{2 0 0 6}$ & $\mathbf{2 0 0 7}$ \\
\hline Labour & 69.6 & 69.3 & 68.9 & 68.6 & 69.3 & 70.2 & 68.7 & 68.6 & 68.5 & 68.7 & 68.3 \\
Goods and services & 22.9 & 21.8 & 22.0 & 23.5 & 23.0 & 21.9 & 22.8 & 23.1 & 24.0 & 24.9 & 25.5 \\
Capital & 7.5 & 8.9 & 9.1 & 7.8 & 7.8 & 7.9 & 8.5 & 8.3 & 7.5 & 6.4 & 6.2 \\
Total & 100.0 & 100.0 & 100.0 & 100.0 & 100.0 & 100.0 & 100.0 & 100.0 & 100.0 & 100.0 & 100.0 \\
\hline
\end{tabular}

Source: Office for National Statistics

is possible to compare the healthcare goods and service price index with an economywide index of costs. This comparison shows how far the different input mix in healthcare has led to a different increase in price indices.

Figure 18 illustrates how the prices of goods and services used as inputs in healthcare have risen, compared to the total rise in home costs per unit of output.

Between 1997 and 2007 the prices of goods and services used in healthcare rose by 10.0 per cent, whereas home costs per unit of output rose by 28.0 per cent over the same period. It is this low rise in input prices that is responsible for the relatively low rise in total input prices compared to other public services. Switching from branded to generic drugs may have played a major role in keeping input price growth low.

Restrained growth in the price of goods and services inputs in healthcare has to some extent offset the relatively high recent growth in labour costs. The overall result is that relative overall input costs in healthcare have risen more slowly than input costs in most other public services. However, because of healthcare's large weight in total public services, this translates into healthcare having the same increase in input costs as the public service (weighted) average.

Figure 19 illustrates the year-by-year movement of goods and service costs in healthcare and compares them with home costs per unit of output for the whole economy.

Key points to note are that:

- the growth in healthcare goods and services input price was below whole economy input price growth in all years, except 1999, 2006 and 2007

- in 2000 and 2005 prices of goods and services in healthcare fell despite positive input price growth in the whole economy

\section{Education}

The other area where it has been possible to investigate a little further is education, which accounts for approximately 19 per cent of total public service spending. Figure 20 brings together the main comparisons for education.

Between 1997 and 2007 key points to note are that:

- relative cost per unit of output rose by 24.4 per cent, an annual average increase of 2.2 per cent

- input per unit of output rose by 4.5 per cent, an annual average increase of 0.4 per cent (equivalent to a fall in productivity of 0.4 per cent)

- relative input prices rose by $19.1 \mathrm{per}$ cent, an annual average increase of 1.8 per cent

- relative cost per unit of output rose in every year since 1998
- relative input prices increased every year until 2007, when they fell slightly

- between 1997 and 1999 input requirements fell, but increased in every year thereafter (that is, productivity fell from 1999 onwards)

Table 6 illustrates the expenditure shares of the broad components of education spending.

Labour is by far the largest component, accounting for over two-thirds of spending in every year. Goods and services account for between one-fifth and one-quarter of the total and are the second largest component. Capital, which for education is measured by capital services, is the smallest component.
Figure 21

\section{Cumulative change in labour costs in education and whole economy, 1997-2007}

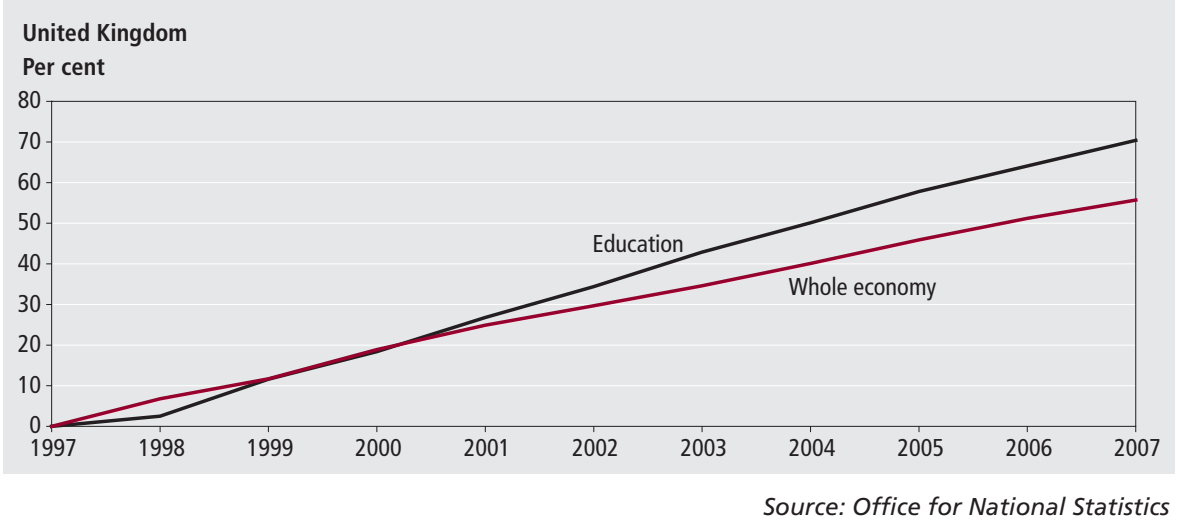

Figure 22

The annual growth rates of labour costs for education and whole economy, 1998-2007

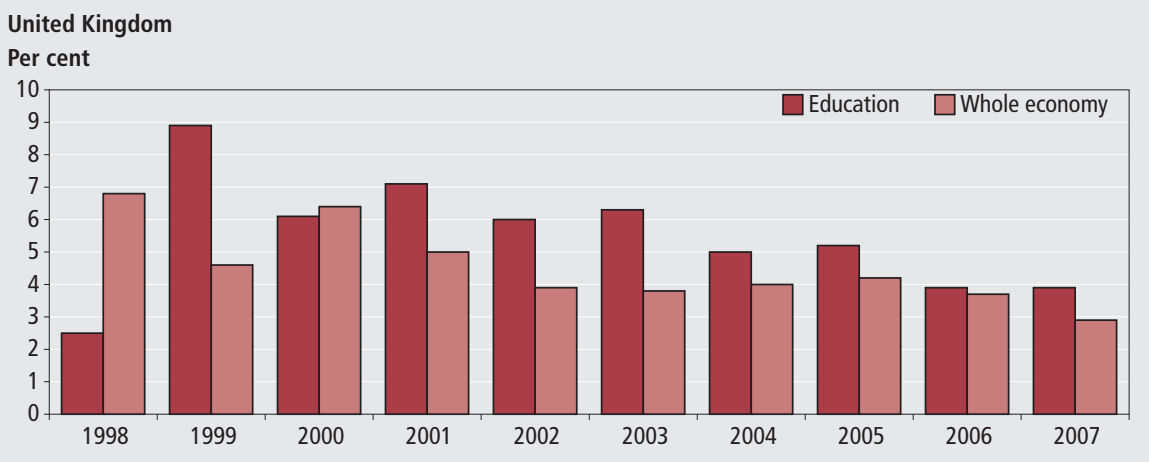




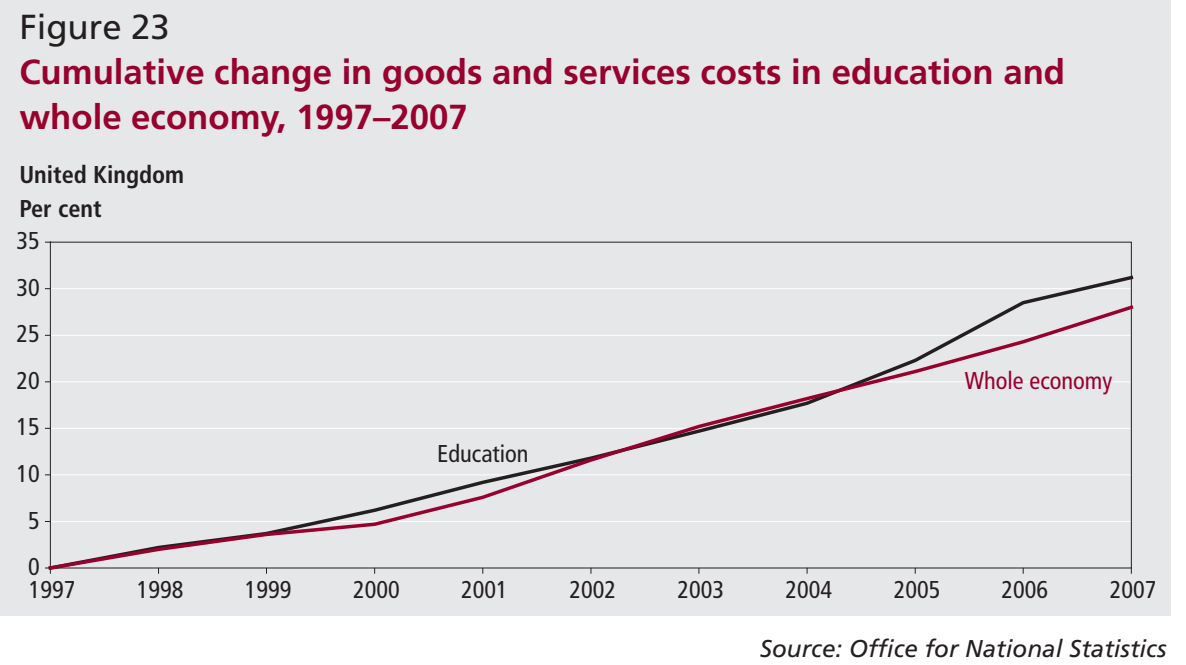

Figure 24

\section{Growth rates of goods and services costs for education and whole economy, 1998-2007}

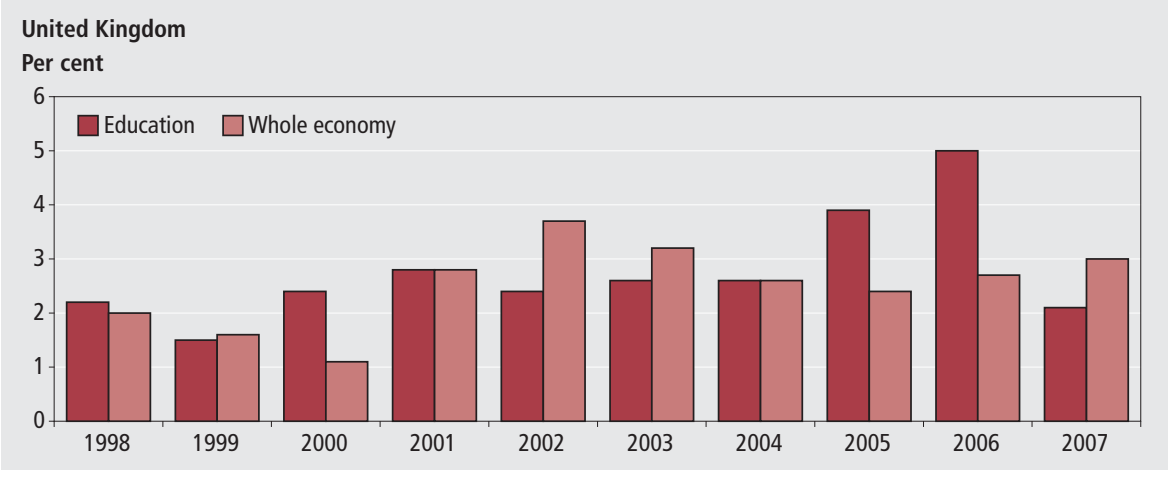

Source: Office for National Statistics

The prices of the component parts of the index can be compared with measures of relevant economy-wide prices or costs. As with healthcare, it was not thought worthwhile to compare the relatively small and volatile capital measure.

Figure 21 shows the index of labour costs in education compared with an index of total labour costs per hour for the whole economy.

Between 1997 and 2007 key points to note are that:

- in 1998 labour costs in education grew slower than in the whole economy

- in 1999 and 2000 the index of labour costs in education had recovered to be almost identical to the whole economy index

- from 2001 labour costs in education stood consistently above the whole economy index

Annual changes for labour costs are illustrated in Figure 22.

Labour costs in education grew faster than in the whole economy in every year except 1998, as already noted, and marginally in 2000 .
Education is labour intensive, hence, the rise in relative unit costs in education are probably due to:

- labour costs per employee rising faster than prices in general

- labour costs per employee in education rising faster than in the whole economy

Some part of the explanation of the rise in labour costs lies in a deliberate policy to improve recruitment to teaching with the aim of increasing the skills of the workforce. Insofar as the policy is successful, the quality of education should improve. However, the existing quality measure in the output of education depends only on GCSE results, so the full effects of any quality improvement would take time to be recorded.

Figure 23 compares the weighted change in the economy-wide prices of those inputs used in education, such as stationery, with an overall economy-wide index of costs.

The indices differ only due to the differences in input mix, though a small gap opens up from 2003 onwards.
Figure 24 illustrates the annual growth rates of goods and services costs in both education and whole economy between 1997 and 2007.

Key points to note are that:

- the goods and service price index for education grew at a noticeably greater rate than those in the whole economy in 2005 and 2006

- the goods and service price index for education grew at the same rate as those in the whole economy in 2001 and 2004

- in 2007 the annual growth rate in the goods and service price index for education was less than that of the whole economy.

\section{Conclusion}

This article has presented estimates of an experimental measure that shows how the cost of a unit of public services has been moving relative to the unit cost of total output. It has shown that public service unit costs have risen because input requirements have increased and the price of inputs has risen relative to unit costs in general. It is the rise in relative input price indices which explains the larger part of the rise in relative output unit costs.

It has not so far been possible to break down the movement in the aggregate price indices into that part explained by public services paying more for the individual inputs and that part explained by public services using relatively more of those inputs growing fastest in price. However, more detailed investigation of healthcare and education suggests that, at least in these areas, the rise in input price indices reflect to some degree faster increases in labour costs than in the wider economy.

Further work will investigate in more detail movements in each sector of the public services.

\section{Notes}

1. Home costs per unit of output provide an estimate of the cost of producing output across the whole economy within the UK.

2. It includes a proportion of public services. It could be argued that it would be better to use a deflator which covered everything except the cost of public services. Further work will investigate the practicability of such a measure.

3. Previously published (ONS 2009a).

4. The categories healthcare, education, adult social care, children's social 
care and public order \& safety are all covered by direct activity measures. In the remaining services, changes in the volume of output continue to be measured by the 'output=inputs' convention. The category referred to in this article as 'other' brings together many smaller spending areas including general public services, economic affairs, environmental protection, housing and community amenities and recreation, culture \& religion.

5. This is the same as for prices per unit of input (since input per unit of output is constant by assumption).

6. For healthcare capital costs are given by capital consumption rather than the theoretically more appropriate measure of capital services.
7. So in the main body of the article, $\mathrm{P}$ is the index of total home costs per unit of output.

\section{CONTACT}

四elmr@ons.gov.uk

\section{REFERENCES}

Atkinson T (2005) Atkinson Review: Final Report: Measurement of Government Output and Productivity for the National Accounts, Palgrave Macmillan:

Basingstoke.

ONS (2008) United Kingdom National Accounts Blue Book 2008, available at: www.statistics.gov.uk/downloads/theme_ economy/BB08.pdf
ONS (2009a) Total Public Service Output and Productivity, available at: www.statistics.gov.uk/articles/nojournal/ TotalPublicServiceFinalv5.pdf

ONS (2009b) Quality-Adjusted Labour Input (experimental), available at: www.statistics.gov.uk/statbase/product. asp?vlnk=14206

ONS (2009c) Capital Services (experimental), available at:

www.statistics.gov.uk/statbase/Product. asp?vInk=14205

Pritchard A (2003) Understanding Government Output and Productivity, available at: www.statistics.gov.uk/articles/nojournal/ GovOutput\&Productivity.pdf

\section{ANNEX A}

\section{Methodology overview}

This section summarises formally the methodology underlying this article.

The implicit price index for public service output can be found by dividing total expenditure on public service output by the index of total public service output. Let this price index be $P_{t}^{p}$ where $t$ is the relevant year. This index is implicit in the calculations of direct output measures already published by ONS, but has not been published since Pritchard (2003). We also denote the corresponding quantity and price indices for inputs as $Q_{t}^{i}$ and $P$, both of which were previously published in Total Public Service Productivity.

As there is no profit income in the public sector, the value of inputs is equal to total spending on public services (that is, the value of output). That is:

$Q_{t}^{p} P_{t}^{p}=Q_{t}^{i} P_{t}^{i}$ or $P_{t}^{p}=\frac{Q_{t}^{i}}{Q_{t}^{p}} P_{t}^{i}$

The ratio $Q_{t}^{i} / Q_{t}^{p}$ may be described as the index of the amount of input required to produce a unit of output. For the analysis below, we denote this index as $I_{t}$. It is obvious from its form that it is simply the reciprocal of the already published productivity index.

The index of the breakdown of the cost in pounds of public service output can be written as

$P_{t}^{p}=I_{t} \cdot P_{t}^{i}$

And the index of costs relative to prices in general can be written as

$P_{t}^{p} / P_{t}=I_{t} \cdot P_{t}^{i} / P_{t}$

where $P_{t}$ is an appropriate index of prices in general ${ }^{7}$.

The movement of this index over time is given by the expression

$\frac{P_{1}^{p}}{P_{0}^{p}} \frac{P_{0}}{P_{1}}=\frac{I_{1}}{I_{0}} \frac{P_{1}^{i}}{P_{0}^{i}} \frac{P_{0}}{P_{1}}$

The body of the paper reports results for the relative unit cost of public service output, $\frac{P_{1}^{p}}{P_{0}^{p}} \frac{P_{0}}{P_{1}}$, and also for the relative cost of public service inputs, $\frac{P_{1}^{i}}{P_{0}^{i}} \frac{P_{0}}{P_{1}}$. The index $\frac{I_{1}}{I_{0}}$ is simply the reciprocal of the standard productivity movement between year 0 and year 1 .

The main text calculates the cost of a unit of public service output relative to total home costs per unit of output. Other comparisons are possible. For example, public service inflation could be compared with a measure of the prices of goods and services making up personal consumption. This would give an indication of how much real consumption was being given up to acquire the given level of public service.

The volume of input required to produce a unit of output is the reciprocal of the productivity measures which have already been published in Total Public Service Output and Productivity. 
The relative price of the inputs used is given by an appropriate expenditure-weighted index of the input prices, estimates of which were also published in Total Public Service Output and Productivity, divided by the index of home costs per unit of output. The product of the index of input per unit of output and the index of relative price per unit of input is an index of the relative unit cost of public service output.

The index of the cost of a unit of public service output is a measure which depends only on the estimates of public service output and total expenditure on public services. It does not depend on the price of inputs or on productivity. If input price growth is over-estimated the consequence is that the volume of input growth will be under-estimated hence, productivity growth overestimated. Errors in estimates of input prices lead to offsetting errors in estimates of input per unit of output, leaving the relative unit cost of public service estimate unchanged.

\section{ANNEX B}

\section{Growth rates}

This section summarises the percentage change at an annual rate of each of the major component tables of this article such that the growth rates between any two periods of each component can easily be identified.

For example, in Table B1 an entry in any cell shows the annual growth rate from the initial year, given by the cell row and the end year, given by the cell column. For example, the coloured figure (0.8) in Table B1 shows the annual growth rate in input per unit of output between the years 2000 (the initial year) and 2003 (the terminal year).

The entries in the bottom of each column show the growth in any year compared to the previous year. The entries along the top row show how annualised growth changes as the end year is updated, for a fixed start year of 1997. The entries in the last column show how annualised growth rates change, as the start year is updated from 1997, for a fixed final year of 2007.

\section{Table B1}

\section{Growth in input per unit output, 1997-2007}

United Kingdom Percentage change, at annual rate

\begin{tabular}{rrrrrrrrrrr}
\hline & 1998 & 1999 & 2000 & 2001 & 2002 & 2003 & 2004 & 2005 & 2006 & 2007 \\
\hline 1997 & -0.2 & 0.2 & 0.5 & 0.3 & 0.5 & 0.6 & 0.6 & 0.6 & 0.5 & 0.3 \\
1998 & & 0.7 & 0.8 & 0.4 & 0.6 & 0.8 & 0.7 & 0.7 & 0.5 & 0.4 \\
1999 & & & 1.0 & 0.3 & 0.6 & 0.8 & 0.7 & 0.7 & 0.5 & 0.4 \\
2000 & & & & -0.4 & 0.4 & 0.8 & 0.7 & 0.7 & 0.4 & 0.3 \\
2001 & & & & & 1.3 & 1.4 & 1.0 & 0.9 & 0.6 & 0.4 \\
2002 & & & & & & 1.5 & 0.9 & 0.8 & 0.5 & 0.2 \\
2003 & & & & & & & 0.3 & 0.5 & 0.1 & -0.1 \\
2004 & & & & & & & & 0.6 & 0.0 & -0.2 \\
2005 & & & & & & & & & -0.6 & -0.6 \\
2006 & & & & & & & & & & -0.6 \\
\hline
\end{tabular}

Source: Office for National Statistics

\section{Table B2}

\section{Growth in relative price per unit input, 1997-2007}

United Kingdom

Percentage change, at annual rate

\begin{tabular}{|c|c|c|c|c|c|c|c|c|c|c|}
\hline & 1998 & 1999 & 2000 & 2001 & 2002 & 2003 & 2004 & 2005 & 2006 & 2007 \\
\hline 1997 & 0.3 & 0.2 & 1.4 & 1.5 & 1.2 & 1.0 & 1.1 & 1.0 & 1.0 & 0.9 \\
\hline 1998 & & 2.4 & 1.9 & 1.9 & 1.4 & 1.2 & 1.2 & 1.1 & 1.1 & 1.0 \\
\hline 1999 & & & 1.4 & 1.6 & 1.0 & 0.8 & 0.9 & 0.9 & 1.0 & 0.8 \\
\hline 2000 & & & & 1.8 & 0.9 & 0.7 & 0.8 & 0.7 & 0.9 & 0.8 \\
\hline 2001 & & & & & -0.1 & 0.1 & 0.5 & 0.5 & 0.7 & 0.6 \\
\hline 2002 & & & & & & 0.2 & 0.8 & 0.7 & 0.9 & 0.7 \\
\hline 2003 & & & & & & & 1.3 & 0.9 & 1.1 & 0.8 \\
\hline 2004 & & & & & & & & 0.5 & 1.0 & 0.7 \\
\hline 2005 & & & & & & & & & 1.5 & 0.8 \\
\hline 2006 & & & & & & & & & & 0.0 \\
\hline
\end{tabular}


Table B3

Growth in cost per unit output, 1997-2007

United Kingdom

\begin{tabular}{|c|c|c|c|c|c|c|c|c|c|c|}
\hline & 1998 & 1999 & 2000 & 2001 & 2002 & 2003 & 2004 & 2005 & 2006 & 2007 \\
\hline 1997 & 2.1 & 0.2 & 3.4 & 3.6 & 3.9 & 4.1 & 4.1 & 4.0 & 4.0 & 3.8 \\
\hline 1998 & & 4.7 & 4.1 & 4.1 & 4.3 & 4.5 & 4.4 & 4.3 & 4.2 & 4.0 \\
\hline 1999 & & & 3.5 & 3.8 & 4.2 & 4.4 & 4.4 & 4.3 & 4.2 & 3.9 \\
\hline 2000 & & & & 4.2 & 4.6 & 4.7 & 4.6 & 4.4 & 4.3 & 4.0 \\
\hline 2001 & & & & & 4.9 & 5.0 & 4.8 & 4.5 & 4.3 & 4.0 \\
\hline 2002 & & & & & & 5.0 & 4.7 & 4.3 & 4.1 & 3.8 \\
\hline 2003 & & & & & & & 4.3 & 3.9 & 3.8 & 3.4 \\
\hline 2004 & & & & & & & & 3.6 & 3.6 & 3.2 \\
\hline 2005 & & & & & & & & & 3.6 & 3.0 \\
\hline 2006 & & & & & & & & & & 2.3 \\
\hline
\end{tabular}

Source: Office for National Statistics

Table B4

Growth in relative cost per unit output, 1997-2007

\begin{tabular}{|c|c|c|c|c|c|c|c|c|c|c|}
\hline \multicolumn{7}{|c|}{ United Kingdom } & \multicolumn{4}{|c|}{ Percentage change, at annual rate } \\
\hline & 1998 & 1999 & 2000 & 2001 & 2002 & 2003 & 2004 & 2005 & 2006 & 2007 \\
\hline 1997 & 0.1 & 0.2 & 1.9 & 1.7 & 1.6 & 1.6 & 1.7 & 1.6 & 1.5 & 1.3 \\
\hline 1998 & & 3.1 & 2.8 & 2.3 & 2.0 & 2.0 & 1.9 & 1.8 & 1.7 & 1.4 \\
\hline 1999 & & & 2.4 & 1.9 & 1.7 & 1.7 & 1.7 & 1.6 & 1.5 & 1.2 \\
\hline 2000 & & & & 1.4 & 1.3 & 1.4 & 1.5 & 1.4 & 1.3 & 1.0 \\
\hline 2001 & & & & & 1.2 & 1.4 & 1.5 & 1.4 & 1.3 & 1.0 \\
\hline 2002 & & & & & & 1.7 & 1.7 & 1.5 & 1.3 & 0.9 \\
\hline 2003 & & & & & & & 1.7 & 1.4 & 1.2 & 0.8 \\
\hline 2004 & & & & & & & & 1.1 & 1.0 & 0.5 \\
\hline 2005 & & & & & & & & & 0.9 & 0.1 \\
\hline 2006 & & & & & & & & & & -0.6 \\
\hline
\end{tabular}

Source: Office for National Statistics 